УДК 371.134.:355.58

DOI:

Василь Ротар, кандидат педагогічних наук, доцент кафедри техніки та засобів сочіального захисту Черкаського інституту пожежної безпеки імені Героїв Чорнобиля

Ігор Ножко, кандидат педагогічних наук, науковий співробітник навчально-наукового-виробничого відділу Черкаського інституту пожежної безпеки імені Героїв Чорнобиля

\title{
ШЛЯХИ ПІДВИЩЕННЯ ПРОФЕСІЙНОЇ КОМПЕТЕНТНОСТІ ФАХІВЦЯ З ПОЖЕЖНОЇ БЕЗПЕКИ
}

Авторами визначено основні шляхи підвищення професійної компетентності фахівия з пожежної безпеки: аналіз професійного середовища з метою виявлення нових можливостей та ресурсів нової системи пожежогасіння; готовність та спроможність самовдосконалюватися; контроль над власною професійною діяльністю; готовність приймати правильні рішення; спонукання інших людей працювати спільно заради поставленої мети; розширення професійного досвіду. Доведено, щуо розвиток професійної компетентності фахівия має відбуватися протягом усього професійного життя.

Ключові слова: фахівець із пожежної безпеки; професійна компетентність; иляхи підвищення професійної компетентності.

Лim. 7.

Vasyl Rotar, Ph.D.(Pedagogy), Associate Professor of the Machinery and Social Security Equipment Department Cherkasy Institute of Fire Safety named after Chornobyl Heroes

Ihor Nozhko, Ph.D.(Pedagogy), Researcher of the Educational-Scientific-Production Department

Cherkasy Institute of Fire Safety named after Chornobyl Heroes

\section{THE WAYS OF INCREASING PROFESSIONAL COMPETENCE OF FIRE SAFETY SPECIALIST}

Actuality of theme. The professional competence of specialist in fire safety includes knowledge of the laws and parameters of the processes of combustion and extinguishing of solid, liquid and gaseous substances and materials, the behavior of building materials and structures in conditions of high temperatures, the action of dangerous factors of fire on living organisms, the functioning of fire service; and yourself as the subject of professional activity.

The purpose of the study is to identify and analyze the ways of enhancing the professional competence of a fire safety specialist.

According to the goal, we outline the following tasks:

1) to analyze the content of the professional competence of a fire safety specialist;

2) to outline the ways of increasing the professional competence of a fire safety specialist

The authors identified the main ways of increasing the professional competence of a fire safety specialist: an analysis of the professional environment in order to identify new opportunities and resources of the new fire extinguishing system; willingness and ability to self-improve; a control over one's professional activity; willingness to make the right decisions; encouraging other people to work together for the purpose; extension of professional experience.

It is argued that the specialist should be able to use oral contacts in situations of professional communication, written contacts in situations of professional communication, reading and comprehension of vocationally oriented and general scientific foreign language literature, its use in social and professional spheres; provide training for facility and population employees on fire safety and training with unit personnel.

It is proved that the extension of the professional experience of a fire safety specialist should include not only quantitative and qualitative changes, but also be consistent with the internal logic of change, which is determined by the passage of certain stages of person's professional career.

Conclusions. The development of professional competence of a specialist should take place throughout the professional life.

The prospects for further scientific exploration are seen in highlighting the results of the experimental verification of the outlined ways of increasing the professional competence of a fire safety specialist.

Keywords: a specialist in fire safety; professional competence; ways to increase professional competence.

П остановка проблеми. Пожежна безпека - сфера діяльності, яка вимагає від фахівців наявності високого рівня професійних знань, практичних навичок. Тому всім співробітникам у галузі пожежної безпеки необхідно володіти високим 
рівнем професійної компетентності. Розвиток професійної компетентності фахівця має відбуватися протягом усього професійного життя.

Професійна компетентність фахівця із пожежної безпеки включає в себе знання про закономірності та параметри процесів горіння і гасіння твердих, рідких і газоподібних речовин і матеріалів, поведінки будівельних матеріалів i конструкцій в умовах високих температур, дії небезпечних факторів пожежі на живі організми, функціонування пожежної служби тощо; про себе як суб'єкта професійної діяльності [7].

Аналіз останніх досліджень і публікацій. В Україні здійснюється пошук шляхів підвищення якості підготовки майбутніх фахівців із пожежної безпеки. Основні концептуальні положення підготовки фахівців у закладах вищої освіти розкривають О. Бикова, М. Варій, Н. Вовчаста, В. Доманський, О. Євсюков, М. Козяр, М. Коваль, М. Кусій, Б. Шуневич та ін.

Проведений нами аналіз показав, що більшість українських педагогів використовують узгоджені трактування понять “компетенція" та “компетентність”. До прикладу, В. Луговий вказує на три позиції, які полягають у використанні таких термінів:

1) “компетентність",

2) “компетенція",

3) “компетентність”, (як інтегральна), що власне, що власне складається з компетенцій (диференціальних) [3, $11-16]$.

У Стандарті професійної (професійно-технічної освіти зазначено, що професійні компетентності - знання та уміння особи, які дають їй змогу виконувати трудові функції, швидко адаптуватися до змін у професійній діяльності та є складовими відповідної професійної кваліфікації [7].

Складна структурна будова професійної компетентності фахівця із пожежної безпеки описана в дослідженнях (Н. Вовчаста [1], I. Красуцька [2], І. Мельник [4]) включає такі компоненти: мотиваційний: прагнення до прояву компетентності у поведінці та діяльності людини; когнітивний: володіння знаннями щодо змісту компетентності, тобто засобами, способами і програмами виконання дій, рішення професійних завдань, реалізації права і норм поведінки; поведінковий: досвід прояву компетентності в різних стандартних і нестандартних ситуаціях; ціннісно-смисловий: наявність особистісної значущості змісту компетентності і об'єкта ï реалізації.

Однак питання розвитку професійної компетентності фахівця із пожежної безпеки не знайшли свого належного відображення у працях сучасних дослідників, що й зумовлює актуальність піднятої проблеми.

Мета дослідження - визначити та проаналізувати шляхи підвищення професійної компетентності фахівця з пожежної безпеки.

Відповідно до поставленої мети, нами окреслено такі завдання:

1)проаналізуватизмістпрофесійної компетентності фахівця із пожежної безпеки;

2) окреслити шляхи підвищення професійної компетентності фахівця із пожежної безпеки.

Виклад основного матеріалу. Ми розглядаємо професійну компетентність фахівця iз пожежної безпеки як “інтегральну характеристику, яка відображатиме мотиваційноціннісні орієнтації особистості, наявність здібностей вирішувати професійні проблеми та завдання, що виникають у реальних ситуаціях професійної діяльності щодо забезпечення пожежної безпеки об'єктів, що охороняються, із використанням знань у різних сферах професійного та життєвого досвіду, умінням здійснювати рефлексію діяльності та самовдосконалення співробітників" [6;7]. Фахівець із пожежної безпеки має бути здатним до систематизації та узагальнення знань із питань забезпечення безпечних умов праці в підрозділах пожежної безпеки; постійно вдосконалювати знання щодо покращення технічних характеристик аварійнорятувального обладнання тощо.

Здійснений аналіз наукових розвідок із питань особливостей професійної діяльності фахівця із пожежної безпеки та його професійної компетентності, стандарту професійної освіти тощо дозволили виокремити такі шляхи підвищення професійної компетентності фахівця iз пожежної безпеки:

- аналіз професійного середовища 3 метою виявлення нових можливостей та ресурсів нової системи пожежогасіння;

- готовність та спроможність самовдосконалюватися;

- контроль над власною професійною діяльністю;

- готовність приймати правильні рішення;

- спонукання інших людей працювати спільно заради поставленої мети;

- розширення професійного досвіду.

Аналіз професійного середовища $з$ метою виявлення нових можливостей та ресурсів нової системи пожежогасіння. Проблема застосування нових технологій пожежогасіння, що дозволяють захищати об'єкт як у цілому, так і окремі його ділянки. Існуючі автоматичні системи виявлення вогнища пожежі не дозволяють із заданою точністю визначати місце локалізації. У зв'язку з 


\section{ШЛЯХИПДВИЩЕННЯПРОФЕСЙНОӤ КОМПЕТЕНТНОСТІФАХІВЦЯЗПОЖЕЖНОӤ БЕЗПЕКИ}

цим часто виникають проблеми щодо забезпечення протипожежного захисту великого числа будівель і приміщень. Тому особливої актуальності набуває проблема удосконалення протипожежного захисту споруд, а особливо - зі складною архітектурою.

Тому розробка алгоритмів виявлення пожежі 3 використанням моделей із просторово розподіленими параметрами, теорій цифрової обробки сигналу й автоматичного управління $\epsilon$ важливим завданням для фахівців із пожежної безпеки. Фахівець повинен чітко знати основні види будівельних матеріалів, їх властивості та класифікацію за походженням, призначенням, способом виготовлення; загальну класифікацію металів і сплавів з металів, їх властивості та галузь застосування; класифікацію, склад, властивості та застосування пластмас, інших полімерних матеріалів; класифікацію гуми i гумотехнічних виробів, їх властивості та галузь застосування тощо [7].

Відтак набуває особливої актуальності питання здійснення дослідницького пошуку нових засобів, технологій, матеріалів тощо 3 протипожежної безпеки. Про ефективність цієї діяльності свідчить сприймання нових знань як джерела інформації та нових понять.

Фахівець із пожежної безпеки має вміти передбачати результати реалізації різних стратегій професійної поведінки та вносити необхідні корективи. Власне таке вміння посилює відчуття впевненості в собі і сприяє досягненню ефективних результатів професійної діяльності. Фахівець має бути готовим помічати, усвідомлювати й аналізувати організаційні, технічні проблеми, що можуть перешкоджати досягненню мети, а відтак - бути готовим долати будь-які перешкоди.

Окрім іншого, фахівець із пожежної безпеки має проявляти особливу увагу до проблем, пов'язаних із досягненням поставлених цілей професійної діяльності.

Тому аналіз професійного середовища з метою виявлення нових можливостей та ресурсів нової системи пожежогасіння $є$ одним із шляхів підвищення професійної компетентності фахівця із пожежної безпеки.

Готовність та спромоюсність самовдосконалюватися. Зауважимо,щоготовність розв'язувати складні задачі $\epsilon$ наслідком стійкої мотивації людини та передбачає готовність аналізувати велику кількість різноманітних факторів, зважуючи їхню відносну значимість. Такий детальний розгляд рідко приводить до простого й однозначного подолання проблеми. Отже, мова йде про постійне самовдосконалення і професійне зростання фахівця.
На жаль, фахівцями 3 пожежної безпеки приділяється недостатньо уваги професійному самовдосконаленню. Очевидно, така ситуація пов'язана з тим, що практики часто плутають уміння вчитися 3 умінням засвоювати “формальну” інформацію. Фахівці мають бути готовими та спроможними самовдосконалюватися; повинні брати активну участь у розробці стратегій саморозвитку; передбачати відкладену в часі оцінку сучасних технологій та новітніх матеріалів, інноваційних ідей у сфері безпеки та оборони.

У контексті сказаного варто наголосити на значимості наполегливості, що знаходить свій прояв у володінні достатнім поведінковим досвідом для усвідомлення важливості стійкості мотивів у процесі рутинної та небезпечної роботи для розв'язання складних професійних задач.

Контроль над власною професійною діяльністю. Чи сформована у фахівця (а в нашому випадку - фахівця із пожежної безпеки) звичка слідкувати за власним просуванням до поставленої мети (самоосвіти, самовдосконалення тощо)? Чи можна 3 упевненістю говорити про можливість підвищити продуктивність праці фахівця із пожежної безпеки, чи проводить людина свідомий розподіл глобальних завдань та здійснює контроль за якістю їхнього виконання. Зауважимо, що без визначення пріоритетних цілей особистість фахівця не може впевнено оцінити власний рівень професійної компетентності.

У розрізі сказаного наголосимо, що реалізація даного аспекту професійного самовдосконалення передбачає усвідомлення людиною того, що вона може здолати будь-які перешкоди, спроможна самостійно контролювати ситуацію та вносити корективи, шукати нові технології та опановувати ними, продукувати нові ідеї, знаходити шляхи засвоєння нових знань тощо.

Готовність приймати правильні рішення. Мається на увазі усвідомлення фахівцем необхідності розуміти ситуацію; дотримання та виконання вимог охорони праці, промислової та пожежної безпеки, виробничої санітарії; передбачення результатів різних способів діяльності та осмислення можливих наслідків для прийняття правильного рішення.

Фахівець із пожежної безпеки повинен:

- приймати виважене рішення під час виконання робіт $з$ протипожежного захисту об'єктів, територій та проведенні аварійнорятувальних робіт;

- використовувати можливості конструктивних і технічних характеристик протипожежної та аварійно-рятувальної техніки, пожежного устаткування, пожежнорятувальних пристроїв, 
інструменту та засобів зв'язку за призначенням під час ліквідації пожеж, дотримуючись правил їх безпечної експлуатації;

- приймати виважене рішення під час виконання робіт з протипожежного захисту об'єктів, територій та проведенні аварійнорятувальних робіт;

- демонструвати культуру мислення та виявляти навички щодо організації культурного діалогу [7].

Як справедливо зазначає I. Мельник, “базисними основами професіоналізму у цій сфері $\epsilon$ прийняття на себе відповідальності за власне рішення, висока організованість, особиста відвага, самокритичність, які значною мірою залежать від структури мотиваційної сфери майбутніх фахівців пожежної безпеки, зокрема узгодженості мотивів влади, взаєморозуміння і досягнення успіхів або уникнення невдач. Переважно, мотиваційна сфера визначає спрямування професіоналізму" [4, 89].

Фахівець із пожежної безпеки може бути не готовим до персональної відповідальності. Це, зазвичай, пов'язано із недосконалим володінням нормативно-правовими актами, що регламентують проведення гасіння пожеж, пожежно-рятувальних, аварійно-рятувальних та інших невідкладних робіт; невпевненістю в собі, відчуттям недостатньої авторитетності; неспроможністю оцінювати стан постраждалих, відсутністю досвіду тощо.

Уникнути такої ситуації можливо лише шляхом свідомого розвитку власних здібностей та прагнення дотримання та виконання вимог охорони праці, промислової і пожежної безпеки, виробничої санітарії; поглиблення правових знань у сфері цивільного захисту, трудового права в професійній діяльності; підвищення рівня знань з основ матеріалознавства та ін.

Спонукання інших людей працювати спільно заради поставленої мети. Цей шлях поєднує у собі спроможність фахівця чітко формулювати цілі та знаходити механізми їхнього досягнення, продукувати ідеї, що оптимізують їхні компетентності, створювати умови для розвитку професійної компетентності. Дуже важливим при цьому є уміння фахівця (а передовсім це стосується керівника) прояснити той факт, що досягнення поставлених цілей стає більш реальним саме в процесі спільної діяльності.

Фахівець повинен уміти застосовувати усні контакти в ситуаціях професійного спілкування, письмові контакти в ситуаціях професійного спілкування, читання й осмислення професійноорієнтованої та загальнонаукової іншомовної літератури, використання і1ї у соціальній і професійній сферах; проводити навчання працівників об'єкта і населення з забезпечення пожежної безпеки та заняття з особовим складом підрозділу [7].

Розширення професійного досвіду. Поетапний процес розширення професійного досвіду передбачає обов'язкове усвідомлення його значимості, сприяє розумінню нової інформації, спонукає до ії аналізу й таким чином прискорює процес зростання компетентності фахівця.

Основою розширення професійного досвіду є прояви індивідуальної активності фахівця. Активність виступає своєрідним результатом саморегуляції.

Професійний досвід фахівця із пожежної безпеки, успішне проходження етапів і рівнів сформованості професійної компетентності багато в чому визначається мотивацією особистості, системою прагнень, ціннісних орієнтацій, сенсу праці фахівця оперативно-рятувальної служби для нього самого. Незважаючи на досить широкий спектр спонукань, що відносяться до мотиваційної сфери, мотивація розширення професійного досвіду значною мірою визначається самою професією [5].

Розширення професійного досвіду фахівця із пожежної безпеки має включати не тільки кількісні та якісні зміни, але й відповідати внутрішній логіці змін, яка визначається проходженням певних етапів професійного шляху людини.

Усвідомлення значимості професійного досвіду, своїх змінених (передовсім позитивних) потенціалів (інший рівень домагань, прагнення підтримати престиж професії фахівця із пожежної безпеки тощо) виступає основним мотивом подальшої професійної активності, спрямованої на підвищення рівня професійної компетентності. Зважаючи на сказане вище, визначаємо домінантний характер професійного досвіду на шляху формування професійної компетентності фахівця із пожежної безпеки.

Доведено, що розширення професійного досвіду, безперервне нагромадження професійних знань, удосконалення умінь і навичок, способів професійної діяльності забезпечує розгортання нових можливостей фахівця, а відтак професійної компетентності.

Висновки. Отже, основними шляхами підвищення професійної компетентності фахівця 3 пожежної безпеки є: аналіз професійного середовища 3 метою виявлення нових можливостей та ресурсів нової системи пожежогасіння; готовність та спроможність самовдосконалюватися; контроль над власною 
професійною діяльністю; готовність приймати правильні рішення; спонукання інших людей працювати спільно заради поставленої мети; розширення професійного досвіду.

Перспективи подалыших наукових розвідок вбачаємо у висвітленні результатів експериментальної перевірки окреслених шляхів підвищення професійної компетентності фахівця із пожежної безпеки.

\section{ЛІТЕРАТУРА}

1. Вовчаста Н. Організаційно-педагогічні умови підготовки фахівців пожежно-рятувальної служби в контексті євроінтеграційних процесів : методичні рекомендації. / за загальною редакцією доктора пед. наук, професора Козяра М.М. Львів, 2010. 115 c.

2. Красуцька І. Експериментальне дослідження формування професійної компетенції пожежниківрятувальників в процесі курсової підготовки. Science Rise: Pedagogical Education. 2018. №3 (23). C. 23-30.

3. Луговий В.І. Освіта, навчання, інформація, компетентність: кононізація понять (теоретикометодологічний дискурс). Історико-педагогічні студї: Науковий часопис. 2011. Вип. 5. С. 1116.

4. Мельник I. Професійна компетентність як компонент професійного стилю спілкування майбутніх фахівців пожежної безпеки. Вісник Черкаського університету. 2016. Вип. 14. С. 8892.

5. Первин Л., Джон О. Психология личности: теория и исследования / Пер. с англ. М.С. Жамкочьян под ред В.С.Магуна. Москва, 2001. 607 с.

6. Ротар В. Професійна компетентність майбутніх спеціалістів: теоретичний аспект. Імідж сучасного педагога. 2014. № 6 (145). С. 22 - 23.

7. Стандарт професійної (професійно-технічної) освіти. Наказ Міністерства освіти і науки України від “06” липня 2018 р. № 731. URL:https:// mon.gov.ua/ua/osvita/profesijno-tehnichna-osvita/

\section{REFERENCES}

1. Vovchasta, N. (2010). Orhanizatsiinopedahohichni umovy pidhotovky fakhivtsiv pozhezhno-riatuvalnoi sluzhby $v$ konteksti yevrointehratsiinykh protsesiv : metodychni rekomendatsii [The organizational and pedagogical conditions of training of specialists of fire-rescue service in the context of European integration processes: methodical recommendations]. (Ed.). Koziar M.M. Lviv, 115 p. [in Ukrainian].

2. Krasutska, I. (2018). Eksperymentalne doslidzhennia formuvannia profesiinoi kompetentsii pozhezhnykiv-riatuvalnykiv v protsesi kursovoi pidhotovky [Experimental study of the formation of professional competence of firefighters in the course of training]. Science Rise: Pedagogical Education. No.3 (23), pp. 23-30. [in Ukrainian].

3. Luhovyi, V.I. (2011). Osvita, navchannia, informatsiia, kompetentnist: kononizatsiia poniat (teoretyko-metodolohichnyi dyskurs) [Education, training, information, competence: the canonization of concepts (the theoretical and methodological discourse)]. Historical and pedagogical studios: Scientific journal.Vol. 5, pp. 11-16. [in Ukrainian].

4. Melnyk, I. (2016). Profesiina kompetentnist yak komponent profesiinoho styliu spilkuvannia maibutnikh fakhivtsiv pozhezhnoi bezpeky [Professional competence as a component of the professional communication style of future fire safety professionals]. Bulletin of Cherkasy University. Vol. 14, pp. 88-92.[in Ukrainian].

5. Pervin, L. \& Dzhon, O. (2001). Psikhologiya lichnosti: teoriya i issledovaniya [Personality Psychology: Theory and Research]. Translation from English. M.S. Zhamkochyan, edited by V.S. Mahun. Moscov, 607 p.[in Russian].

6. Rotar, V. (2014). Profesiina kompetentnist maibutnikh spetsialistiv: teoretychnyi aspekt [Professional competence of future specialists: theoretical aspect]. The image of the modern teacher. No. 6 (145), pp. 22 - 23. [in Ukrainian].

7. Standart profesiinoi (profesiino-tekhnichnoi) osvity [The standard of professional (vocational) education]. Order of the Ministry of Education and Science of Ukraine of July 06, 2018 No. 731. Available at: https://mon.gov.ua/ua/osvita/profesijno-tehnichnaosvita/[in Ukrainian].

Стаття надійшла до редакції 23.09.2019

\section{G5808012058080}

"ТТи не впадеш, якщо не підійлаєшся в гору. Але яка радість від иілого життя, проведеного на землі".

Невідомий автор

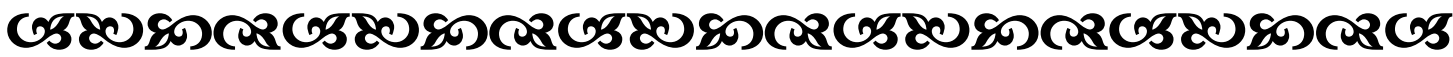

